Brit. J. industr. Med., 1965, 22, 109.

\title{
VENTILATORY CAPACITY IN FLAX WORKERS IN NORTHERN IRELAND
}

\author{
BY \\ G. C. R. CAREY, J. D. MERRETT, P. C. ELWOOD, J. PEMBERTON, \\ and I. R. MCAULAY \\ From the Department of Social and Preventive Medicine, The Queen's University of Belfast
}

(RECEIVED FOR PUBLICATION AUGUST 27, 1964)

Of 2,528 persons aged 35 years and over who were interviewed during a survey of Northern Ireland flax mills, $2,003(79 \%)$ carried out tests of one-second forced expiratory volume (F.E.V.1.0) and forced vital capacity (F.V.C.) which were suitable for analysis. The omission of the remaining 525 workers is discussed in the text.

The object of this paper is to compare each of these two measurements of ventilatory capacity between preparers and non-preparers of flax in this industry.

Many factors, other than job, may influence ventilatory capacity; these include sex, smoking habits, the area of the mill, the type of fibre handled, byssinotic grade, age, and stem height. Within each sex and job, workers were divided into eight basic groups according to whether they did or did not smoke, whether the mill was in a town or rural area, and whether the mill processed only flax or flax plus synthetic fibres. Within each of these basic groups of non-byssinotic non-preparers, regression equations of the type

$$
Y=a+b_{1} X_{1}+b_{2} X_{2}
$$

where $Y=$ predicted F.E.V.1.0 ${ }$ or F.V.C. (litres), $X_{1}=$ age (years), $X_{2}=$ stem height (cm.), and $a, b_{1}$, and $b_{2}$ are constants derived from the data, were calculated for non-byssinotic non-preparers. These equations were used to predict the F.E.V. $\cdot_{\cdot \cdot \cdot 0}$ and F.V.C. of byssinotic and non-byssinotic preparers in each basic group, for each sex separately. The average predicted ventilatory capacity of preparers was then compared with the corresponding averaged observed ventilatory capacity.

It was found that (1) byssinotic flax preparers had a lower mean F.E.V.1.0 and F.V.C. than did comparable groups of non-byssinotic non-preparers, (2) non-byssinotic preparers had a lower average $F . E . V_{\cdot 1 \cdot 0}$ than did non-byssinotic non-preparers, (3) there is some evidence that preparers with symptoms of grade I or II byssinosis had a lower F.E.V. $\cdot_{1 \cdot 0}$ than did preparers with no, or only slight, symptoms of byssinosis (grades 0 and $\frac{1}{2}$ respectively).

It has been shown that cardroom and blowroom workers in the cotton industry who have byssinosis have significantly lower ventilatory capacities than similar workers without byssinosis (Schilling, Hughes, Dingwall-Fordyce, and Gilson, 1955).

The object of this paper is to compare the measurements of forced expiratory volume in one-second (F.E.V.1.0 $)$ and of forced vital capacity (F.V.C.) between preparers and non-preparers of flax in Northern Ireland. The measurements were made during a survey of byssinosis and other respiratory symptoms in flax workers, the clinical findings of which have been previously reported (Elwood, Pemberton, Merrett, Carey, and McAulay, 1965).
Altogether 2,528 workers were seen in the survey and of these $2,003(79 \%)$ performed lung function tests suitable for analysis (Tables 1 and 2); the reasons for excluding 525 from the analysis are shown in Table 3.

In the first mills visited the measurements of F.E.V.1.0 and F.V.C. were made with a Gaensler (1951) spirometer. Subsequently a Poulton spirometer was used because it had been shown to be easier to calibrate (McKerrow, McDermott, and Gilson, 1960). It was found, however, after a series of tests that the two instruments did not give strictly comparable results, and the 236 Gaensler results were therefore omitted. 
TABLE 1

DISTRIBUTION OF PREPARERS WHO COMPLETED LUNG FUNCTION TESTS BY BASIC GROUP* AND BYSSINOSIS GRADE

\begin{tabular}{|c|c|c|c|c|c|c|}
\hline \multirow{2}{*}{$\underset{\text { Group* }}{\text { Basic }}$} & \multicolumn{6}{|c|}{ Byssinosis Grade } \\
\hline & 0 & $\frac{1}{2}$ & I & II & Past & Total \\
\hline $\begin{array}{rr}\text { Males } & \\
& 1 \\
2 & \\
3 \\
4 \\
4 \\
5 \\
6 \\
7 \\
7 \\
8\end{array}$ & $\begin{array}{rr}3 & (6) \\
31 & (38) \\
4 & (13) \\
18 & (24) \\
5 & (10) \\
18 & (22) \\
4 & (10) \\
13 & (13)\end{array}$ & $\begin{array}{rr}6 & (7) \\
18 & (20) \\
2 & (6) \\
4 & (4) \\
1 & (1) \\
2 & (2) \\
3 & (3) \\
3 & (4)\end{array}$ & $\begin{array}{cc}2 & (6) \\
7 & (8) \\
3 & (6) \\
4 & (8) \\
4 & (1) \\
2 & (4) \\
1 & (6) \\
1 & (1)\end{array}$ & $\begin{array}{c}2 \text { (2) } \\
8(12) \\
2(4) \\
6(14) \\
-1(1) \\
2 \quad(3) \\
2 \quad(2)\end{array}$ & $\begin{array}{l}=(二) \\
=(二) \\
1(\text { (1) } \\
=(二) \\
=(二) \\
=(二)\end{array}$ & $\begin{aligned} 13 & (21) \\
64 & (78) \\
11 & (29) \\
33 & (51) \\
6 & (12) \\
25 & (29) \\
8 & (22) \\
19 & (20)\end{aligned}$ \\
\hline Total & $96(136)$ & $36(47)$ & $23(40)$ & $23(38)$ & 1 (1) & $179(262)$ \\
\hline $\begin{array}{r}\text { Females } \\
1 \\
2 \\
3 \\
4 \\
5 \\
6 \\
7 \\
8\end{array}$ & $\begin{array}{rr}24 & (32) \\
28 & (31) \\
25 & (33) \\
17 & (19) \\
73 & (106) \\
106 & (120) \\
42 & (90) \\
60 & (65)\end{array}$ & $\begin{array}{r}8(10) \\
9(11) \\
4(10) \\
5(6) \\
9(12) \\
16(16) \\
7(12) \\
4(4)\end{array}$ & 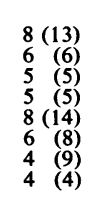 & $\begin{array}{ll}6 & (8) \\
3 & (3) \\
1 & (2) \\
3 & (3) \\
6 & (8) \\
2 & (3) \\
3 & (7) \\
3 & (3)\end{array}$ & $\begin{array}{l}=(二) \\
=(二) \\
=(\text { (二) } \\
1 \text { (2) } \\
=(二) \\
=(-)\end{array}$ & $\begin{array}{rr}46 & (63) \\
46 & (51) \\
35 & (50) \\
30(33) \\
97(142) \\
130(147) \\
56(118) \\
71(76)\end{array}$ \\
\hline Total & 375 (496) & $62(81)$ & $46(64)$ & $27(37)$ & 1 (2) & $511(680)$ \\
\hline
\end{tabular}

(1) The number of workers who completed clinical interviews are shown in parentheses.

*(2) Basic sub-groups are defined in the text; in brief, at the time of the survey workers in:

(a) groups 1 to 4 were smokers and groups 5 to 8 were non-smokers;

(b) groups $1,2,5$, and 6 were handling only flax, and groups $3,4,7$, and 8 were handling flax and synthetic fibres;

(c) groups 1,3 , 5, and 7 were working in town mills, and groups $2,4,6$, and 8 were working in country mills.

TABLE 2

DISTRIBUTION OF NON-PREPARERS WHO COMPLETED LUNG FUNCTION TESTS BY BASIC GROUP* AND BYSSINOSIS GRADE

\begin{tabular}{|c|c|c|c|c|c|c|}
\hline \multirow{2}{*}{$\underset{\text { Group* }}{\text { Basic }}$} & \multicolumn{6}{|c|}{ Byssinosis Grade } \\
\hline & $\mathbf{0}$ & $\frac{1}{2}$ & $\mathbf{I}$ & II & Past & Total \\
\hline $\begin{array}{rr}\text { Males } & \\
& 1 \\
2 \\
3 \\
3 \\
4 \\
5 \\
6 \\
7 \\
7 \\
8\end{array}$ & $\begin{array}{r}52(75) \\
87(112) \\
50(59) \\
117(121) \\
29(43) \\
51(59) \\
23(29) \\
56 \quad(63)\end{array}$ & 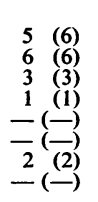 & $\begin{array}{l}\frac{2}{(2)}\left(\frac{2)}{(1)}\right. \\
=(\text { (一) } \\
=(二) \\
=(二) \\
=(二)\end{array}$ & $\begin{array}{l}-1(-) \\
1 \text { (1) } \\
=(\text { (二) } \\
=(二) \\
=(二) \\
=(二)\end{array}$ & $\begin{array}{cc}2 & (2) \\
1 & (1) \\
2 & (2) \\
1 & (1) \\
\frac{2}{2} & \left(\frac{1}{(3)}\right) \\
1 & \left(\frac{1}{(1)}\right)\end{array}$ & $\begin{array}{r}61(85) \\
95(120) \\
57(66) \\
119(123) \\
29(43) \\
53(62) \\
25(31) \\
57(64)\end{array}$ \\
\hline Total & $465(561)$ & $17(18)$ & $3(3)$ & $2(2)$ & $9(10)$ & $496(594)$ \\
\hline $\begin{array}{r}\text { Females } \\
1 \\
2 \\
3 \\
4 \\
5 \\
6 \\
7 \\
8\end{array}$ & $\begin{array}{r}90(101) \\
59(68) \\
58(77) \\
54(58) \\
126(154) \\
165(197) \\
89(137) \\
165(186)\end{array}$ & $\begin{array}{l}\overline{1}(1) \\
\overline{(1)} \\
\overline{3}(-) \\
=(\text { ( }) \\
=(二) \\
=(二)\end{array}$ & $\begin{array}{l}1 \text { (2) } \\
=(\text { (二) } \\
=(二) \\
=(\text { (云) } \\
=\text { (云) } \\
=(二)\end{array}$ & $\begin{array}{l}1 \text { (1) } \\
=(\text { (二) } \\
=(\text { (二) } \\
=(\text { (二) } \\
=(\text { (二) }\end{array}$ & 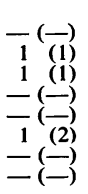 & $\begin{array}{r}92(105) \\
61(70) \\
59(78) \\
54(58) \\
129(157) \\
168(201) \\
89(137) \\
165(186)\end{array}$ \\
\hline Total & $806(978)$ & 4 (5) & 3 (4) & 1 (1) & 3 (4) & 817 (992) \\
\hline
\end{tabular}

See footnote (1) to Table 1.

*See footnote (2) to Table 1 .

One hundred and three male and 156 female workers failed to come to the examination room where the spirometer was set up. These persons were questioned at their machines at a later date about their symptoms, but it was found impracticable to carry out lung function tests under these condi- tions. Forty-two of the 103 men and 101 of the 156 women were at work in the mill but refused to attend for interview. The remaining 61 men and 55 women were absent according to the factory nominal rolls for the day. The bias caused by the omission of these data is considered later in this paper. Finally, there 
TABLE 3

DISTRIBUTION OF 2,528 WORKERS AGED 35 YEARS AND OVER WHO WERE SURVEYED, BY SEX AND WHETHER OR NOT SATISFACTORY LUNG FUNCTION TESTS WERE CARRIED OUT

\begin{tabular}{l|r|r|r}
\hline \multicolumn{1}{c|}{ Reasons for Exclusion } & M & F & Total \\
\hline Gaensler apparatus used & 68 & 168 & 236 \\
Physical or mental disability & 10 & 20 & 30 \\
Interviewed in work-rooms & 103 & 156 & 259 \\
\hline Total exclusions & 181 & 344 & 525 \\
\hline Total tested satisfactorily & 675 & 1,328 & 2,003 \\
\hline Total & 856 & 1,672 & 2,528 \\
\hline
\end{tabular}

were 30 subjects who, because of physical disabilities, e.g., cleft palate or mental subnormality or overanxiety, could not perform the test satisfactorily.

The arithmetic mean of the F.E.V $\cdot_{\cdot 1 \cdot 0}$ and F.V.C. derived from the last three of five technically satisfactory blowings was used for analysis. The volumes were corrected for temperature differences between alveolar and ambient air temperature but not for daily barometric changes since errors from this latter source are small.

All the lung function tests were carried out by one observer (G.C.R.C.) on Tuesdays, Wednesdays or Thursdays, and neither the byssinotic grade nor the occupation of the worker was known to him at the time.

\section{Definitions}

Byssinosis.-Four grades of byssinosis, as generally used in surveys of textile workers (Roach and Schilling, 1960), and two occupational groups are used for the analysis and are fully defined in the earlier report (Elwood et al., 1965). Abbreviated definitions are as follows:

Grade 0: No byssinosis.

Grade $\frac{1}{2}$ : Some tightness of the chest or breathlessness on some Mondays.

Grade I: Some tightness of the chest or breathlessness on every Monday but not on other days.

Grade II: The same symptoms as above on every Monday and on other days as well (previously confined to Monday).

Occupation.-Occupations in the mills were grouped as follows:

Preparers: Roughers, sorters, hacklers, carders, etc., and combers, spreaders, drawers, doublers, and dry gill spinners.

Non-preparers: Wet finishers; reelers, winders, bundlers; maintenance men, mechanics, electricians.
Location of Mill in Town or Country.-In an attempt to allow for the possible influence of air pollution on the respiratory function, mills were classified as 'town mills' when they were situated within the boundary of an urban area with 5,000 or more population. All other mills were designated 'country mills'.

Smoking.-Subjects were classified as 'smokers' if they had smoked at least one cigarette a day or its equivalent for at least the immediately preceding year, and all others as 'non-smokers'.

Duration of Exposure.-The period of exposure was divided into $(a)$ the number of years spent working in preparing rooms, and $(b)$ the number of years spent working in non-preparing rooms.

Type of Fibre.-Mills were classified as either (a) processing flax only, or (b) processing flax and synthetic fibres.

Stem Height.-This was taken as the vertical distance (in $\mathrm{cm}$.) from the vertex of the head to the surface of the seat of a wooden chair on which the individual was sitting.

\section{Analysis}

If either byssinosis or working in a preparing room adversely affects lung function, then, when other relevant factors are held constant, an average estimate of lung function is likely to be lower in a group of byssinotic workers or in a group of preparers than in a random sample of the general population from which the byssinotics and preparers are drawn.

Data relating to the distribution of F.E.V $\cdot_{\cdot 1 \cdot 0}$ and F.V.C. in the general population of Northern Ireland are not available, therefore data relating to the F.E.V.1.0 and F.V.C. of non-byssinotic nonpreparers were used.

There were, however, 525 flax workers for whom data relating to ventilatory capacity are not available or have been excluded (Table 3). In the analysis which follows it is assumed that the results are not biassed by these omissions. This assumption is probably justified in the case of the 236 workers excluded because the Gaensler spirometer was used, as we have no reason to believe that there was a specially selected population in these two mills. The omission of the small group of 30 workers on grounds of physical (unrelated to occupation) or mental disability must be accepted, for measurements of ventilatory capacity in such persons are likely to be an under-estimate and will bias the results. There 
remains the group of 259 refusals and absentees, for whom it may be argued that the less fit did not attend for lung function tests. This may be true in the case of male preparers in that $72 \%$ of those without symptoms of byssinosis had lung function tests whereas, of those with grade I and II byssinosis, only $59 \%$ had lung function tests. However, the reverse is true in male non-preparers, and in female preparers and non-preparers the percentages of persons with or without byssinotic symptoms who had lung function tests are very similar. In any case the likely bias arising from the exclusion of these male preparers and non-preparers will reduce rather than increase the differences found between the ventilatory capacity of preparers and non-preparers.

'Secondary' factors, in addition to primary factors of job (preparers or non-preparers) and byssinosis grade, associated with F.E.V.1.0 or F.V.C. include age, sex, atmospheric pollution, and tobacco smoking; all of these are known to be associated with the prevalence of chest symptoms (Higgins, 1957; Ogilvie and Newell, 1957; College of General Practitioners, 1961) and respiratory function measurements (Needham, Rogan, and McDonald, 1954; Pemberton and Macleod, 1956; McKerrow, McDermott, Gilson, and Schilling, 1958). Stem height must also be included among the 'secondary' factors because of its known association with respiratory function measurements (Hurtado and Fray, 1933). In addition it seemed likely that the type of fibre handled and the number of years worked in preparing or non-preparing rooms might affect the lung function measurements.

Data relating to these 'secondary' factors were obtained at the interview of each worker, and workers of each sex were classified into the following eight basic groups with respect to those secondary factors which could not be adequately expressed as measurements :

1. Smokers handling only flax in town mills;

2. Smokers handling only flax in country mills;

3. Smokers handling flax and synthetic fibres in town mills;

4. Smokers handling flax and synthetic fibres in country mills;

5. Non-smokers handling only flax in town mills;

6. Non-smokers handling only flax in country mills;

7. Non-smokers handling flax and synthetic fibres in town mills;

8. Non-smokers handling flax and synthetic fibres in country mills.

The remaining secondary factors (age, stem height, duration of exposure in preparing rooms and/or non-preparing rooms) are 'measurements' which were used as independent variables in regression equations derived from data relating to nonbyssinotic non-preparers for each of the eight basic groups in the following sets:

Set A. To predict F.E.V.1.0 for males;

Set B. To predict F.E.V.:1.0 for females;

Set C. To predict F.V.C. for males;

Set D. To predict F.V.C. for females.

The mean age and stem height of preparers and non-preparers in each of the basic groups are tabulated in Table 4.

The equations were of the form

$$
Y=a+b_{1} X_{1}+b_{2} X_{2}+b_{3} X_{3}+b_{4} X_{4}
$$

where $Y$ is the predicted value of F.E.V.1.0 or F.V.C. (litres), $X_{1}$ is the age (years), $X_{2}$ is the stem height (cm.), $X_{3}$ is the duration of exposure in preparing rooms (years), $X_{4}$ is the duration of exposure in nonpreparing rooms (years), and $a, b_{1}, b_{2}, b_{3}$, and $b_{4}$ are constants estimated from the data.

Only age and stem height consistently made significant contributions (at the $\mathbf{P}<0.05$ level used throughout this analysis) to the predictions. In four of the 32 equations the coefficients of the duration of exposure in preparing rooms were significant-this occurred in basic groups 6 and 7 in both sets A and $C$, but within each set the signs of the significant coefficients were opposed, being negative in basic group 6 and positive in basic group 7 . Only in four equations were the coefficients of duration of exposure in non-preparing rooms significant. This occurred in basic group 2 of sets $\mathrm{A}$ and $\mathrm{C}$, and in basic group 1 of sets $B$ and $D$.

It was shown that the omission of the two duration-of-exposure variates significantly reduced the sum of squares due to regression in only three basic groups $(2,5$, and 7$)$ of sets $A$ and $C$, and in only one basic group (1) of sets B and D.*

The two variates relating to durations of exposure were therefore omitted from further analyses, partly because of the inconsistency of the signs of the few significant coefficients; partly because their contributions to prediction were generally negligible; and partly because their inclusion would have resulted in extrapolation beyond their ranges when the regression equations were applied to sub-groups of preparers within basic groups. Such extrapolation would have arisen because, generally within the industry, preparers had spent most of their working lives in preparing rooms whereas non-preparers had spent most of their working lives in non-preparing rooms.

\footnotetext{
*These analyses are available on request.
} 
TABLE 4

MEAN AGE AND STEM HEIGHT OF PREPARERS (BY BYSSINOSIS GRADE) AND NON-BYSSINOTIC NON-PREPARERS

\begin{tabular}{|c|c|c|c|c|c|c|c|c|c|c|c|c|}
\hline \multirow{4}{*}{$\underset{\text { Group }}{\text { Basic }}$} & \multicolumn{6}{|c|}{ Males } & \multicolumn{6}{|c|}{ Females } \\
\hline & \multicolumn{5}{|c|}{ Preparers } & \multirow{3}{*}{$\begin{array}{c}\text { Non-preparers } \\
\begin{array}{c}\text { Byssinosis } \\
\text { Grade }\end{array} \\
0\end{array}$} & \multirow{2}{*}{\multicolumn{5}{|c|}{\begin{tabular}{|c|} 
Preparers \\
Byssinosis Grade
\end{tabular}}} & \multirow{3}{*}{$\begin{array}{c}\text { Non-preparers } \\
\begin{array}{c}\text { Byssinosis } \\
\text { Grade }\end{array} \\
\mathbf{0}\end{array}$} \\
\hline & \multicolumn{5}{|c|}{ Byssinosis Grade } & & & & & & & \\
\hline & 0 & $\frac{1}{2}$ & I & II & $\overline{\frac{1}{2}+\mathbf{I}+\mathbf{I I}}$ & & 0 & $\frac{1}{2}$ & I & II & $\overline{\frac{1}{2}+I+I I}$ & \\
\hline $1 \stackrel{(a)}{(b)}$ & $\begin{array}{l}3 \\
45 \cdot 00 \\
90 \cdot 00\end{array}$ & $\begin{array}{l}6 \\
56 \cdot 00 \\
87 \cdot 17\end{array}$ & $\begin{array}{l}2 \\
49 \cdot 00 \\
89 \cdot 50\end{array}$ & $\begin{array}{c}2 \\
56 \cdot 50 \\
89 \cdot 00\end{array}$ & $\begin{array}{l}10 \\
54 \cdot 70 \\
88.00\end{array}$ & $\begin{array}{l}52 \\
52 \cdot 58 \\
87 \cdot 11\end{array}$ & $\begin{array}{l}24 \\
43.92 \\
82.92\end{array}$ & $\begin{array}{l}8 \\
42 \cdot 88 \\
83 \cdot 38\end{array}$ & $\begin{array}{c}8 \\
40 \cdot 63 \\
81 \cdot 50\end{array}$ & $\begin{array}{c}6 \\
46 \cdot 17 \\
83.00\end{array}$ & $\begin{array}{l}22 \\
42.95 \\
82 \cdot 59\end{array}$ & $\begin{array}{l}90 \\
44 \cdot 02 \\
82 \cdot 31\end{array}$ \\
\hline $2 \stackrel{(a)}{(b)}$ & $\begin{array}{l}31 \\
48 \cdot 39 \\
87.03\end{array}$ & $\begin{array}{l}18 \\
51 \cdot 11 \\
86 \cdot 72\end{array}$ & $\begin{array}{c}7 \\
48 \cdot 29 \\
85 \cdot 43\end{array}$ & $\begin{array}{c}8 \\
52 \cdot 88 \\
87 \cdot 88\end{array}$ & $\begin{array}{l}33 \\
50.94 \\
86.73\end{array}$ & $\begin{array}{l}87 \\
51 \cdot 45 \\
87 \cdot 37\end{array}$ & $\begin{array}{l}28 \\
41 \cdot 79 \\
82.07\end{array}$ & $\begin{array}{c}99 \\
43 \cdot 44 \\
83 \cdot 11\end{array}$ & $\begin{array}{c}6 \\
43 \cdot 33 \\
83 \cdot 17\end{array}$ & $\begin{array}{c}3 \\
47 \cdot 33 \\
79 \cdot 33\end{array}$ & $\begin{array}{l}18 \\
44 \cdot 06 \\
82 \cdot 50\end{array}$ & $\begin{array}{l}59 \\
46 \cdot 15 \\
82 \cdot 14\end{array}$ \\
\hline $3 \begin{array}{l}(a) \\
(b)\end{array}$ & $\begin{array}{c}4 \\
46 \cdot 75 \\
87 \cdot 50\end{array}$ & $\begin{array}{c}2 \\
45.00 \\
85.50\end{array}$ & $\begin{array}{l}3 \\
52.00 \\
82.67\end{array}$ & $\begin{array}{c}2 \\
54 \cdot 50 \\
81 \cdot 50\end{array}$ & $\begin{array}{c}7 \\
50 \cdot 71 \\
83 \cdot 14\end{array}$ & $\begin{array}{l}50 \\
52 \cdot 28 \\
88 \cdot 00\end{array}$ & $\begin{array}{l}25 \\
42.00 \\
83.92\end{array}$ & $\begin{array}{c}4 \\
45 \cdot 75 \\
80 \cdot 75\end{array}$ & $\begin{array}{c}5 \\
40 \cdot 40 \\
83 \cdot 20\end{array}$ & $\begin{array}{c}1 \\
35.00 \\
77.00\end{array}$ & $\begin{array}{l}10 \\
42.00 \\
81.60\end{array}$ & $\begin{array}{l}58 \\
45.03 \\
82.07\end{array}$ \\
\hline $4 \stackrel{(a)}{(b)}$ & $\begin{array}{l}18 \\
50 \cdot 22 \\
84 \cdot 00\end{array}$ & $\begin{array}{c}4 \\
56 \cdot 25 \\
88 \cdot 25\end{array}$ & $\begin{array}{c}4 \\
48 \cdot 00 \\
90 \cdot 50\end{array}$ & $\begin{array}{c}6 \\
54 \cdot 67 \\
83 \cdot 33\end{array}$ & $\begin{array}{l}14 \\
53.21 \\
86.79\end{array}$ & $\begin{array}{c}117 \\
51.09 \\
86.63\end{array}$ & $\begin{array}{l}17 \\
41 \cdot 41 \\
81 \cdot 53\end{array}$ & $\begin{array}{c}5 \\
44.00 \\
80 \cdot 00\end{array}$ & $\begin{array}{c}5 \\
51.00 \\
82.00\end{array}$ & $\begin{array}{c}3 \\
40 \cdot 00 \\
79 \cdot 33\end{array}$ & $\begin{array}{l}13 \\
45 \cdot 77 \\
80 \cdot 62\end{array}$ & $\begin{array}{l}54 \\
44 \cdot 54 \\
82 \cdot 65\end{array}$ \\
\hline $5 \stackrel{(a)}{(b)}$ & $\begin{array}{c}5 \\
48 \cdot 60 \\
89 \cdot 80\end{array}$ & $\begin{array}{r}1 \\
55.00 \\
88.00\end{array}$ & $=$ & 二 & $\begin{array}{r}1 \\
55.00 \\
88.00\end{array}$ & $\begin{array}{l}29 \\
48 \cdot 41 \\
88.03\end{array}$ & $\begin{array}{l}73 \\
50 \cdot 41 \\
81 \cdot 23\end{array}$ & $\begin{array}{c}9 \\
50.00 \\
83.33\end{array}$ & $\begin{array}{c}8 \\
48 \cdot 75 \\
81 \cdot 00\end{array}$ & $\begin{array}{c}6 \\
51.67 \\
81.67\end{array}$ & $\begin{array}{l}23 \\
50.00 \\
82.09\end{array}$ & $\begin{array}{r}126 \\
49.04 \\
82.55\end{array}$ \\
\hline $6 \begin{array}{l}(a) \\
(b) \\
(c)\end{array}$ & $\begin{array}{l}18 \\
52 \cdot 72 \\
88 \cdot 33\end{array}$ & $\begin{array}{c}2 \\
45.00 \\
87.00\end{array}$ & $\begin{array}{c}4 \\
50 \cdot 00 \\
89 \cdot 50\end{array}$ & $\begin{array}{c}1 \\
58.00 \\
88.00\end{array}$ & $\begin{array}{c}7 \\
49 \cdot 71 \\
88 \cdot 57\end{array}$ & $\begin{array}{l}51 \\
52 \cdot 16 \\
87 \cdot 47\end{array}$ & \begin{tabular}{|c|}
106 \\
$48 \cdot 51$ \\
83.02
\end{tabular} & $\begin{array}{l}16 \\
50 \cdot 75 \\
82 \cdot 19\end{array}$ & $\begin{array}{c}6 \\
52.33 \\
82.67\end{array}$ & $\begin{array}{c}2 \\
58.00 \\
81.00\end{array}$ & $\begin{array}{l}24 \\
51.75 \\
82.21\end{array}$ & $\begin{array}{r}165 \\
48.89 \\
82.87\end{array}$ \\
\hline $7 \begin{array}{l}(a) \\
(b) \\
(c)\end{array}$ & $\begin{array}{c}4 \\
55 \cdot 50 \\
84 \cdot 25\end{array}$ & $=$ & $\begin{array}{c}2 \\
51.50 \\
92 \cdot 50\end{array}$ & $\begin{array}{c}2 \\
58 \cdot 50 \\
84 \cdot 50\end{array}$ & $\begin{array}{c}4 \\
55 \cdot 00 \\
88 \cdot 50\end{array}$ & $\begin{array}{l}23 \\
47 \cdot 17 \\
88 \cdot 17\end{array}$ & $\begin{array}{l}42 \\
54 \cdot 10 \\
82 \cdot 67\end{array}$ & $\begin{array}{c}7 \\
46.00 \\
82.71\end{array}$ & $\begin{array}{c}4 \\
48 \cdot 50 \\
82 \cdot 50\end{array}$ & $\begin{array}{c}3 \\
59.67 \\
79.00\end{array}$ & $\begin{array}{l}14 \\
49 \cdot 64 \\
81 \cdot 86\end{array}$ & $\begin{array}{l}89 \\
50 \cdot 10 \\
82 \cdot 19\end{array}$ \\
\hline $8 \stackrel{(a)}{(b)}$ & $\begin{array}{l}13 \\
52.23 \\
84.69\end{array}$ & $\begin{array}{c}3 \\
57 \cdot 67 \\
85 \cdot 33\end{array}$ & $\begin{array}{c}1 \\
37.00 \\
87.00\end{array}$ & $\begin{array}{c}2 \\
50 \cdot 50 \\
88.00\end{array}$ & $\begin{array}{c}6 \\
51 \cdot 83 \\
86 \cdot 50\end{array}$ & $\begin{array}{l}56 \\
50 \cdot 48 \\
87 \cdot 32\end{array}$ & $\begin{array}{l}60 \\
48 \cdot 70 \\
81 \cdot 90\end{array}$ & $\begin{array}{c}4 \\
43 \cdot 75 \\
81 \cdot 75\end{array}$ & $\begin{array}{c}4 \\
48 \cdot 25 \\
83 \cdot 25\end{array}$ & $\begin{array}{c}3 \\
49 \cdot 33 \\
80 \cdot 67\end{array}$ & $\begin{array}{l}11 \\
46.91 \\
82.00\end{array}$ & $\begin{array}{c}165 \\
50 \cdot 82 \\
82.09\end{array}$ \\
\hline
\end{tabular}

*See footnote (2) to Table 1.

(a) Number of workers; (b) Average age in years; (c) Average stem height in $\mathrm{cm}$.

Therefore, for non-byssinotic non-preparers regression equations of lung function estimates on age and stem height were derived for each of the eight basic groups in each of the four sets mentioned above. Within each set, the variation about the regression line was similar in all the eight basic groups as is shown by the values of $\chi^{2}$ derived from Bartlett's test at the foot of Table 5. The multiple correlation coefficients indicated a reasonably high degree of consistent correlation of F.E.V. $\cdot_{1 \cdot 0}$ and F.V.C. with age and stem height (Table 5). Within each set there were no significant differences between slopes; however, within sets A, B, and D there were significant differences between positions (Table 6). Therefore for each set regression coefficients common to all basic groups were derived although different constants for each had to be calculated. The final equations are shown in Table 7.

The constants of these equations are compatible with the known effects of smoking habits and living in town or country. For a given age and stem height, differences between constants within a set reflected differences between the expected average F.E.V.1.0, or F.V.C., between basic groups. Thus we would expect the constants of basic groups 1, 2, 3, and 4 to be lower than those of basic groups 5,6 , 7 , and 8 , respectively, because the former were composed of smokers and the latter of non-smokers; this expectation was fulfilled in sets A and B, which related to estimates of F.E.V.1.0 inconsistencies in sets $C$ and $D$, which related to F.V.C. Likewise we would expect the constants of basic groups $1,3,5$, and 7 to be lower than those of basic groups $2,4,6$, and 8 , respectively, because the former were composed of workers in town mills and the latter of workers in country mills; this expectation was consistently fulfilled in all sets.

The possible effects of handling only flax or flax and synthetic fibres can similarly be considered by comparing the constants of basic groups $1,2,5$, and 6 with those of basic groups $3,4,7$, and 8 , respectively. The former, composed of workers handling flax only, were consistently lower than the latter, composed of workers handling flax and synthetic fibres, in sets B and D for women, but there were inconsistencies in sets $\mathrm{A}$ and $\mathrm{C}$ for men.

No formal tests of significance support the last two paragraphs beyond the general tests of Table 5 
TABLE 5

MULTIPLE CORRELATION COEFFICIENT (R), STANDARD DEVIATION FROM REGRESSION (s), AND DEGREES OF FREEDOM (D.F.) FROM REGRESSION ANALYSES WITHIN BASIC GROUPS* OF (a) F.E.V.1. ON AGE AND STEM HEIGHT, AND (b) F.V.C. ON AGE AND STEM HEIGHT FROM DATA RELATING TO NON-BYSSINOTIC NON-PREPARERS

\begin{tabular}{|c|c|c|c|c|c|}
\hline \multirow{2}{*}{$\underset{\text { Group* }}{\text { Basic }}$} & \multicolumn{2}{|c|}{ F.E.V.$_{1 \cdot 0}$ on Age and Stem Height } & \multicolumn{2}{|c|}{ F.V.C. on Age and Stem Height } & \multirow{2}{*}{ D.F. } \\
\hline & $\mathbf{R}$ & $\underset{\text { (litres) }}{\mathbf{s}}$ & $\mathbf{R}$ & $\begin{array}{c}\mathrm{s} \\
\text { (litres) }\end{array}$ & \\
\hline $\begin{array}{r}\text { Males } \\
1 \\
2 \\
3 \\
4 \\
5 \\
6 \\
7 \\
8\end{array}$ & $\begin{array}{l}0.6677 \\
0.6438 \\
0.7607 \\
0.6457 \\
0.7489 \\
0.6926 \\
0.7306 \\
0.6394\end{array}$ & $\begin{array}{l}0.5029 \\
0.5158 \\
0.4237 \\
0.5824 \\
0.5301 \\
0.5860 \\
0.7046 \\
0.5619\end{array}$ & $\begin{array}{l}0.5962 \\
0.6166 \\
0.7289 \\
0.6398 \\
0.7367 \\
0.6881 \\
0.6461 \\
0.6232\end{array}$ & $\begin{array}{l}0.5779 \\
0.5929 \\
0.5398 \\
0.6140 \\
0.6213 \\
0.6633 \\
0.8419 \\
0.6238\end{array}$ & $\begin{array}{r}49 \\
84 \\
47 \\
114 \\
26 \\
48 \\
20 \\
53\end{array}$ \\
\hline $\begin{array}{r}\text { Females } \\
1 \\
2 \\
3 \\
4 \\
5 \\
6 \\
7 \\
8\end{array}$ & $\begin{array}{l}0.5673 \\
0.5814 \\
0.6960 \\
0.4357 \\
0.6343 \\
0.6218 \\
0.5999 \\
0.6039\end{array}$ & $\begin{array}{l}0.3845 \\
0.4158 \\
0.2900 \\
0.3298 \\
0.3683 \\
0.3714 \\
0.3701 \\
0.3775\end{array}$ & $\begin{array}{l}0.6056 \\
0.5360 \\
0.7148 \\
0.5599 \\
0.6221 \\
0.6181 \\
0.6714 \\
0.5495\end{array}$ & $\begin{array}{l}0.4159 \\
0.4365 \\
0.3372 \\
0.3664 \\
0.4219 \\
0.4147 \\
0.3661 \\
0.4642\end{array}$ & $\begin{array}{r}87 \\
56 \\
55 \\
51 \\
123 \\
162 \\
86 \\
162\end{array}$ \\
\hline \multicolumn{6}{|c|}{ Test of homogeneity of residual variances from regression } \\
\hline $\begin{array}{l}\text { Males } \\
\text { Females }\end{array}$ & $\begin{array}{l}\chi^{2}=11 \cdot 05, \mathrm{D} \\
\chi^{2}=8 \cdot 78, \mathrm{D}\end{array}$ & $\begin{array}{l}P>0.10 \\
P>0.20\end{array}$ & $\begin{array}{l}x^{2}=7 \cdot 50, \text { D } \\
x^{2}=12 \cdot 69, \mathrm{D}\end{array}$ & $\begin{array}{l}P>0.30 \\
P>0.05\end{array}$ & \\
\hline
\end{tabular}

*See footnote (2) to Table 1.

All values of $R$ are significant at $P<0.01$.

TABLE 6

COMPARISON OF REGRESSIONS AND CONSTANTS OBTAINED FROM REGRESSION ANALYSES WITHIN BASIC GROUPS* OF (a) F.E.V. ${ }_{1 \cdot 0}$ ON AGE AND STEM HEIGHT AND (b) F.V.C. ON AGE AND STEM HEIGHT FROM DATA RELATING TO NON-BYSSINOTIC NON-PREPARERS

\begin{tabular}{|c|c|c|c|c|c|c|c|c|c|}
\hline \multirow[b]{2}{*}{$\begin{array}{l}\text { Source of } \\
\text { Variation }\end{array}$} & \multirow[b]{2}{*}{ D.F. } & \multicolumn{4}{|c|}{ F.E.V. ${ }_{1 \cdot 0}$} & \multicolumn{4}{|c|}{ F.V.C. } \\
\hline & & $\begin{array}{l}\text { Sum of } \\
\text { Squares } \\
\left(\text { litres }^{2}\right)\end{array}$ & $\begin{array}{c}\text { Mean } \\
\text { Square } \\
\text { (litres') }\end{array}$ & $\begin{array}{c}\text { Variance } \\
\text { Ratio }\end{array}$ & $\mathbf{P}$ & $\begin{array}{l}\text { Sum of } \\
\text { Squares } \\
\text { (litres }^{2} \text { ) }\end{array}$ & $\begin{array}{c}\text { Mean } \\
\text { Square } \\
\text { (litres }^{2} \text { ) }\end{array}$ & $\begin{array}{c}\text { Variance } \\
\text { Ratio }\end{array}$ & $\mathbf{P}$ \\
\hline $\begin{array}{l}\text { Males } \\
\text { Total regression } \\
\text { Between slopes } \\
\text { Between positions } \\
\text { Residual }\end{array}$ & $\begin{array}{r}2 \\
14 \\
7 \\
441\end{array}$ & $\begin{array}{r}114 \cdot 2240 \\
3 \cdot 6950 \\
5 \cdot 7930 \\
132 \cdot 2926\end{array}$ & $\begin{array}{r}57 \cdot 1120 \\
0.2639 \\
0.8276 \\
0.3000\end{array}$ & $\begin{array}{r}190 \cdot 37 \\
<1 \\
2 \cdot 76\end{array}$ & $\begin{array}{c}<0.001 \\
>0.20 \\
0.001-0.01\end{array}$ & $\begin{array}{r}126 \cdot 5453 \\
4 \cdot 2787 \\
2 \cdot 4617 \\
168 \cdot 5226\end{array}$ & $\begin{array}{r}63 \cdot 2727 \\
0 \cdot 3056 \\
0 \cdot 3517 \\
0 \cdot 3821\end{array}$ & $\begin{array}{l}165 \cdot 59 \\
<1 \\
<1\end{array}$ & $\begin{array}{l}<0.001 \\
>0.20 \\
>0.20\end{array}$ \\
\hline Total & 464 & 256.0046 & & & & $301 \cdot 8083$ & & & \\
\hline $\begin{array}{l}\text { Females } \\
\text { Total regression } \\
\text { Between slopes } \\
\text { Between positions } \\
\text { Residual }\end{array}$ & $\begin{array}{r}2 \\
14 \\
7 \\
782\end{array}$ & $\begin{array}{r}57 \cdot 2138 \\
1.0737 \\
7 \cdot 0117 \\
106.6021\end{array}$ & $\begin{array}{r}28.6069 \\
0.0767 \\
1.0017 \\
0.1363\end{array}$ & $\begin{array}{c}209 \cdot 88 \\
<1 \\
7 \cdot 35\end{array}$ & $\begin{array}{l}<0.001 \\
>0.20 \\
<0.001\end{array}$ & $\begin{array}{r}78.0633 \\
0.9927 \\
4.6729 \\
135.0087\end{array}$ & $\begin{array}{r}39.0317 \\
0.0709 \\
0.6676 \\
0.1726\end{array}$ & $\begin{array}{c}226 \cdot 14 \\
<1 \\
3 \cdot 87\end{array}$ & $\begin{array}{l}<0.001 \\
>0.20 \\
<0.001\end{array}$ \\
\hline Total & 805 & 171.9013 & & & & $218 \cdot 7376$ & & & \\
\hline
\end{tabular}

*See footnote (2) to Table 1.

which indicated significant differences in positions between the basic groups in all sets except $C$. The main concern here was to show that the differences can be explained, and, apart from some inconsistency in F.V.C., the explanations are reasonable.

For each basic group of each set the average expected lung function estimates $(Y)$ of non-byssinotic and byssinotic preparers were calculated from the appropriate regression equations for non-byssinotic non-preparers given in Table 7. These expected averages were then compared with the corresponding observed averages $(\bar{y})$ by calculating the standard error of each deviation $(\bar{y}-Y)$, i.e., the observed minus predicted average F.E.V.1.0 or F.V.C. Clearly, if all deviations were negative and significant then the evidence in favour of the hypothesis that preparers have a lower average F.E.V.1.0 or F.V.C. than nonbyssinotic non-preparers of the same average age and stem height would be formidable.

Unfortunately, the numbers of preparers in some 
TABLE 7

REGRESSION EQUATIONS USED TO PREDICT (a) F.E.V.1.0 and (b) F.V.C. FROM AGE AND STEM HEIGHT IN SUB-GROUPS OF WORKERS WITHIN EACH OF THE BASIC GROUPS

$\mathbf{Y}=\mathbf{a}+\mathrm{b}_{1} \mathbf{X}_{1}+\mathrm{b}_{2} \mathbf{X}_{2}$

WHERE $X_{1}=$ AGE IN YEARS, $X_{2}=$ STEM HEIGHT IN CM., AND Y $=$ PREDICTED F.E.V.1.॰ OR F.V.C. IN LITRES, AND OTHER SYMBOLS HAVE VALUES AS SHOWN

\begin{tabular}{|c|c|c|c|c|}
\hline \multirow{2}{*}{$\begin{array}{c}\text { Basic } \\
\text { Group* }\end{array}$} & \multicolumn{2}{|c|}{$Y=$ F.E.V.1.0 (litres) } & \multicolumn{2}{|c|}{$Y=$ F.V.C. (litres) } \\
\hline & Males & Females & Males & Females \\
\hline \multicolumn{5}{|c|}{ a values } \\
\hline $\begin{array}{l}1 \\
2 \\
3 \\
4 \\
5 \\
6 \\
7 \\
8\end{array}$ & $\begin{array}{l}0 \cdot 1990 \\
0.2982 \\
0 \cdot 2203 \\
0 \cdot 2357 \\
0.3923 \\
0.4120 \\
0.3720 \\
0.5533\end{array}$ & $\begin{array}{r}-0.0142 \\
0.1839 \\
0.0887 \\
0.2127 \\
0.1120 \\
0.2312 \\
0.2212 \\
0.2981\end{array}$ & $\begin{array}{r}-0.1945 \\
-0.0018 \\
-0.0767 \\
-0.0127 \\
-0.0698 \\
-0.0513 \\
0.0507 \\
0.0768\end{array}$ & $\begin{array}{l}0 \cdot 1806 \\
0 \cdot 3248 \\
0 \cdot 2186 \\
0.3323 \\
0.1458 \\
0 \cdot 2692 \\
0 \cdot 2833 \\
0 \cdot 3660 \\
\end{array}$ \\
\hline \multicolumn{5}{|c|}{$b_{1}$ values } \\
\hline All groups & $-0.0414 \pm 0.0027$ & $-0.0277 \pm 0.0017$ & $-0.0400 \pm 0.0031$ & $-0.0302 \pm 0.0019$ \\
\hline \multicolumn{5}{|c|}{$b_{2}$ values } \\
\hline All groups & $0.0525 \pm 0.0063$ & $0.0385 \pm 0.0040$ & $0.0675 \pm 0.0071$ & $0.0467 \pm 0.0045$ \\
\hline \multicolumn{5}{|c|}{ Variance from regression } \\
\hline Within groups & $0 \cdot 3000$ & $0 \cdot 1363$ & 0.3821 & $0 \cdot 1726$ \\
\hline
\end{tabular}

* See footnote (2) to Table 1 .

Standard errors follow \pm signs.

of the sub-groups were very few, consequently deviations large enough to be of physiological importance could not always have been detected as significant. In an attempt to meet this problem a simple sign test has been used to supplement the evidence of significant deviations.

If the null hypothesis, i.e., that preparers and non-preparers have similar lung function estimates, other factors being equal, was true, the theoretically expected value of a deviation would be zero and the probability of observing a negative deviation by chance would be $\mathbf{0 . 5}$. Most of the comparisons which follow were made in sets of 16 , one for each basic group of each sex. If significantly more than eight were negative, it was likely that the null hypothesis was false. Where relevant, the probability is shown of observing, by chance, on the null hypothesis, as many negative deviations as in fact occurred. When this probability was small $(<0.025)$ and the number of negative deviations was greater than half the possible number (usually half of 16), it follows that the null hypothesis was unlikely. In applying sign tests it was confirmed that the proportion of negative deviations in the basic groups of each sex were approximately the same.

\section{Results}

F.E.V..$_{1 \cdot 0}$ in Non-byssinotic and Byssinotic Preparers.-Table 8 shows the deviations in average
F.E.V.1.0 (observed minus expected) for nonbyssinotic (grade 0 ) preparers and byssinotic (grades $\frac{1}{2}$, I, and II combined) preparers in each of the eight basic groups of each sex. For non-byssinotic preparers, only one deviation was significant in each sex, and both were negative. The deviations were negative in six of the eight basic groups of men and in seven of the eight groups of women. On the null hypothesis, the probability of observing by chance as many as 13 negative deviations out of 16 deviations is low, 0.011 . The deviations ranged from -0.39 to +0.23 litre in the male basic groups and from -0.17 to +0.09 litre in the female groups.

For byssinotic preparers, three deviations in male groups and four in female groups were significant, and all were negative. The deviations were negative in seven of the eight basic groups of men and in all eight groups of women. On the null hypothesis, the probability of observing by chance as many as 15 negative out of 16 deviations is very low, $0 \cdot 0003$. The deviations ranged from -1.02 to +0.16 litres in male basic groups and from -0.27 to -0.06 litre in the female basic groups. The value of -1.02 litres was exceptional; if it is excluded the range becomes -0.43 to +0.16 litre in the male groups.

Although the deviations were often small, some of their standard errors were relatively large, consequently the $95 \%$ confidence limits for these deviations are given in Table 10. The imprecise nature of some of the estimates among the male groups clearly 
TABLE 8

EXPECTED AND OBSERVED AVERAGE F.E.V.1.0 OF NON-BYSSINOTIC (GRADE 0) AND BYSSINOTIC (GRADES 1 , I AND II) PREPARERS IN EACH BASIC GROUP*

\begin{tabular}{|c|c|c|c|c|c|c|c|}
\hline \multirow{2}{*}{$\underset{\text { Group* }}{\text { Basic }}$} & \multirow{2}{*}{$\begin{array}{c}\text { Byssinosis } \\
\text { Grade } \dagger\end{array}$} & \multirow{2}{*}{$\begin{array}{l}\text { No. of } \\
\text { Workers }\end{array}$} & \multicolumn{2}{|c|}{ Mean F.E.V.1.0 (litres) } & \multirow{2}{*}{$\begin{array}{c}\begin{array}{c}\text { Deviation } \\
\text { (litres) }\end{array} \\
\mathbf{O}-\mathrm{E}\end{array}$} & \multirow{2}{*}{$\begin{array}{l}\text { Standard } \\
\text { Error } \\
\text { (litres) } \\
\text { (S.E.) }\end{array}$} & \multirow{2}{*}{$\frac{(O-E)}{\text { S.E. }}$} \\
\hline & & & $\begin{array}{c}\text { Observed } \\
\text { (O) }\end{array}$ & $\begin{array}{l}\text { Expected } \\
\text { (E) }\end{array}$ & & & \\
\hline $\begin{array}{c}\text { Males } \\
1\end{array}$ & $\underset{\mathbf{B}}{\mathbf{N}}$ & $\begin{array}{r}3 \\
10\end{array}$ & $\begin{array}{l}2 \cdot 70 \\
2 \cdot 12\end{array}$ & $\begin{array}{l}3.06 \\
2.55\end{array}$ & $\begin{array}{l}-0.36 \\
-0.43\end{array}$ & $\begin{array}{l}0.32 \\
0.18\end{array}$ & $\begin{array}{l}-1 \cdot 13 \\
-2 \cdot 46 \ddagger\end{array}$ \\
\hline 2 & $\stackrel{\mathbf{N}}{\mathbf{B}}$ & $\begin{array}{l}31 \\
33\end{array}$ & $\begin{array}{l}2 \cdot 68 \\
2 \cdot 58\end{array}$ & $\begin{array}{l}2 \cdot 86 \\
2 \cdot 74\end{array}$ & $\begin{array}{l}-0 \cdot 18 \\
-0 \cdot 16\end{array}$ & $\begin{array}{l}0 \cdot 10 \\
0 \cdot 10\end{array}$ & $\begin{array}{l}-1.77 \\
-1.62\end{array}$ \\
\hline 3 & $\begin{array}{l}\mathbf{N} \\
\mathbf{B}\end{array}$ & $\begin{array}{l}4 \\
7\end{array}$ & $\begin{array}{l}2 \cdot 78 \\
2 \cdot 07\end{array}$ & $\begin{array}{l}2 \cdot 88 \\
2 \cdot 49\end{array}$ & $\begin{array}{l}-0.10 \\
-0.42\end{array}$ & $\begin{array}{l}0.28 \\
0.21\end{array}$ & $\begin{array}{l}-0.36 \\
-1.99 \ddagger\end{array}$ \\
\hline 4 & $\begin{array}{l}\mathbf{N} \\
\mathbf{B}\end{array}$ & $\begin{array}{l}18 \\
14\end{array}$ & $\begin{array}{l}2 \cdot 44 \\
2 \cdot 38\end{array}$ & $\begin{array}{l}2 \cdot 57 \\
2 \cdot 59\end{array}$ & $\begin{array}{l}-0.13 \\
-0.21\end{array}$ & $\begin{array}{l}0.13 \\
0.15\end{array}$ & $\begin{array}{l}-0.98 \\
-1.42\end{array}$ \\
\hline 5 & $\begin{array}{l}\mathbf{N} \\
\mathbf{B}\end{array}$ & $\begin{array}{l}5 \\
1\end{array}$ & $\begin{array}{l}3 \cdot 30 \\
2 \cdot 90\end{array}$ & $\begin{array}{l}3.09 \\
2 \cdot 74\end{array}$ & $\begin{array}{l}0.21 \\
0.16\end{array}$ & $\begin{array}{l}0.25 \\
0.55\end{array}$ & $\begin{array}{l}0.85 \\
0.29\end{array}$ \\
\hline 6 & $\stackrel{\mathbf{N}}{\mathbf{B}}$ & $\begin{array}{r}18 \\
7\end{array}$ & $\begin{array}{l}2 \cdot 48 \\
2 \cdot 67\end{array}$ & $\begin{array}{l}2.87 \\
3.00\end{array}$ & $\begin{array}{l}-0.39 \\
-0.33\end{array}$ & $\begin{array}{l}0 \cdot 13 \\
0 \cdot 21\end{array}$ & $\begin{array}{l}-2.97 \ddagger \\
-1.58\end{array}$ \\
\hline 7 & $\begin{array}{l}\mathbf{N} \\
\mathbf{B}\end{array}$ & $\begin{array}{l}4 \\
4\end{array}$ & $\begin{array}{l}2.73 \\
1.73\end{array}$ & $\begin{array}{l}2.50 \\
2 \cdot 75\end{array}$ & $\begin{array}{r}0.23 \\
-1.02\end{array}$ & $\begin{array}{l}0.28 \\
0.28\end{array}$ & $\begin{array}{c}0.83 \\
-\mathbf{3} \cdot 70 \ddagger\end{array}$ \\
\hline 8 & $\begin{array}{l}\mathbf{N} \\
\mathbf{B}\end{array}$ & $\begin{array}{r}13 \\
6\end{array}$ & $\begin{array}{l}2 \cdot 66 \\
2 \cdot 67\end{array}$ & $\begin{array}{l}2 \cdot 84 \\
2 \cdot 95\end{array}$ & $\begin{array}{l}-0 \cdot 18 \\
-0 \cdot 28\end{array}$ & $\begin{array}{l}0 \cdot 15 \\
0 \cdot 22\end{array}$ & $\begin{array}{l}-1 \cdot 16 \\
-1.25\end{array}$ \\
\hline$\underset{1}{\text { Females }}$ & $\begin{array}{l}\mathbf{N} \\
\mathbf{B}\end{array}$ & $\begin{array}{l}24 \\
22\end{array}$ & $\begin{array}{l}2.05 \\
1.82\end{array}$ & $\begin{array}{l}1.96 \\
1.98\end{array}$ & $\begin{array}{r}0.09 \\
-0.16\end{array}$ & $\begin{array}{l}0.08 \\
0.08\end{array}$ & $\begin{array}{c}1 \cdot 18 \\
-2 \cdot 01 \ddagger\end{array}$ \\
\hline 2 & $\underset{\mathbf{B}}{\mathbf{N}}$ & $\begin{array}{l}28 \\
18\end{array}$ & $\begin{array}{l}2 \cdot 15 \\
2 \cdot 08\end{array}$ & $\begin{array}{l}2 \cdot 19 \\
2 \cdot 14\end{array}$ & $\begin{array}{l}-0.04 \\
-0.06\end{array}$ & $\begin{array}{l}0.07 \\
0.09\end{array}$ & $\begin{array}{l}-0.56 \\
-0.68\end{array}$ \\
\hline 3 & $\begin{array}{l}\mathbf{N} \\
\mathbf{B}\end{array}$ & $\begin{array}{l}25 \\
10\end{array}$ & $\begin{array}{l}2 \cdot 15 \\
1.86\end{array}$ & $\begin{array}{l}2 \cdot 16 \\
2 \cdot 07\end{array}$ & $\begin{array}{l}-0.01 \\
-0.21\end{array}$ & $\begin{array}{l}0.08 \\
0.12\end{array}$ & $\begin{array}{l}-0.13 \\
-1.79\end{array}$ \\
\hline 4 & $\begin{array}{l}\mathbf{N} \\
\mathbf{B}\end{array}$ & $\begin{array}{l}17 \\
13\end{array}$ & $\begin{array}{l}2.04 \\
1.90\end{array}$ & $\begin{array}{l}2.20 \\
2.05\end{array}$ & $\begin{array}{l}-0 \cdot 16 \\
-0.15\end{array}$ & $\begin{array}{l}0.09 \\
0.10\end{array}$ & $\begin{array}{l}-1.77 \\
-1.45\end{array}$ \\
\hline 5 & $\begin{array}{l}\mathbf{N} \\
\mathbf{B}\end{array}$ & $\begin{array}{l}73 \\
23\end{array}$ & $\begin{array}{l}1.80 \\
1.62\end{array}$ & $\begin{array}{l}1.84 \\
1.89\end{array}$ & $\begin{array}{l}-0.04 \\
-0.27\end{array}$ & $\begin{array}{l}0.05 \\
0.08\end{array}$ & $\begin{array}{l}-0 \cdot 88 \\
-3 \cdot 47 \ddagger\end{array}$ \\
\hline 6 & $\stackrel{\mathbf{N}}{\mathbf{B}}$ & $\begin{array}{r}106 \\
24\end{array}$ & $\begin{array}{l}2.02 \\
1.79\end{array}$ & $\begin{array}{l}2.08 \\
1.96\end{array}$ & $\begin{array}{l}-0.06 \\
-0.17\end{array}$ & $\begin{array}{l}0.04 \\
0.08\end{array}$ & $\begin{array}{l}-1 \cdot 58 \\
-2 \cdot 23 \ddagger\end{array}$ \\
\hline 7 & $\stackrel{\mathbf{N}}{\mathbf{B}}$ & $\begin{array}{l}42 \\
14\end{array}$ & $\begin{array}{l}1.74 \\
1.73\end{array}$ & $\begin{array}{l}1.91 \\
2.00\end{array}$ & $\begin{array}{l}-0.17 \\
-0.27\end{array}$ & $\begin{array}{l}0.06 \\
0.10\end{array}$ & $\begin{array}{l}-2.90 \ddagger \\
-2 \cdot 72 \ddagger\end{array}$ \\
\hline 8 & $\begin{array}{l}\mathbf{N} \\
\mathbf{B}\end{array}$ & $\begin{array}{l}60 \\
11\end{array}$ & $\begin{array}{l}2.01 \\
1.97\end{array}$ & $\begin{array}{l}2 \cdot 10 \\
2 \cdot 16\end{array}$ & $\begin{array}{l}-0.09 \\
-0.19\end{array}$ & $\begin{array}{l}0.05 \\
0.11\end{array}$ & $\begin{array}{l}-1.82 \\
-1.70\end{array}$ \\
\hline
\end{tabular}

*See footnote (2) to Table 1.

$\dagger \mathbf{N}=$ byssinosis grade $\mathbf{0} ; \mathbf{B}=$ byssinosis grades $\frac{1}{2}, \mathbf{I}$ and II.

†Significant at $\mathbf{P}<0.05$.

demands some caution in generalizing from our estimates.

There were six basic groups of men and seven of women in which the deviations were negative both for the byssinotic and the non-byssinotic sub-groups (Table 8). In four out of these six male groups and six out of these seven female groups, the negative deviations were of greater magnitude in the byssinotic than in the non-byssinotic sub-groups within the same basic group. This observation is compatible with the hypothesis that byssinotic preparers suffer greater impairment of lung function than nonbyssinotic preparers. On the null hypothesis, the probability of observing by chance, out of 13 pairs, as many as 10 pairs of deviations in which one par- ticular member is greater than another is low, 0.046 .

In the remaining basic groups of both men and women, where the signs of the deviations in the byssinotic and the non-byssinotic sub-groups were not both negative, the former always had the less favourable average $F . E . V_{\cdot 1 \cdot 0}$. In one basic group of men and in one of women, the byssinotic sub-group had a significant negative deviation while the nonbyssinotic sub-group had a positive, but not significant, deviation.

There is considerable overlap of the $95 \%$ confidence limits of the deviations of the byssinotic and non-byssinotic sub-groups within most basic groups, and in only one of the 16 groups are they discrete. 
F.V.C. in Non-byssinotic and Byssinotic Preparers.-Table 9 shows the deviations in average F.V.C. (observed minus expected) for non-byssinotic (grade 0) preparers and byssinotic (grades $\frac{1}{2}$, I, and II combined) preparers in each of the eight basic groups of each sex. For non-byssinotic preparers, only one deviation was significant in each sex, and both were negative. The deviations were negative in six of the eight basic groups of men and in five of the eight basic groups of women. On the null hypothesis, the probability of observing by chance as many as 11 negative deviations out of 16 deviations is 0.105 , which is not technically significant. The deviations ranged from -0.47 to +0.33 litre in the male basic groups and from -0.14 to +0.08 litre in the female basic groups.
For byssinotic preparers, four deviations in male groups and one in female groups were significant; all significant deviations were negative. The deviations were negative in six out of the eight basic groups of men and in all eight of the female groups. On the null hypothesis, the probability of observing by chance as many as 14 negative deviations out of 16 deviations is very low, 0.002 . The deviations ranged from -0.77 to +0.03 litre in the male basic groups and from -0.21 to -0.07 litre in the female basic groups. The value of -0.77 was exceptional; if it is excluded, the range becomes -0.50 to +0.03 litre in the male groups.

As with F.E.V.1.0, the deviations were often small, and some of their standard errors were large; con. sequently, the $95 \%$ confidence limits for the devia.

TABLE 9

EXPECTED AND OBSERVED AVERAGE F.V.C. OF NON-BYSSINOTIC (GRADE 0) AND BYSSINOTIC (GRADES $\frac{1}{2}, 1$ AND II) PREPARERS IN EACH BASIC GROUP*

\begin{tabular}{|c|c|c|c|c|c|c|c|}
\hline \multirow{2}{*}{$\underset{\text { Group* }}{\text { Basic }}$} & \multirow{2}{*}{$\begin{array}{c}\text { Byssinosis } \\
\text { Grade } †\end{array}$} & \multirow{2}{*}{$\begin{array}{l}\text { No. of } \\
\text { Workers }\end{array}$} & \multicolumn{2}{|c|}{ Mean F.V.C. (litres) } & \multirow{2}{*}{$\begin{array}{c}\text { Deviation } \\
\text { (litres) } \\
\text { O - E }\end{array}$} & \multirow{2}{*}{$\begin{array}{c}\text { Standard } \\
\text { Error } \\
\text { (litres) } \\
\text { (S.E.) }\end{array}$} & \multirow{2}{*}{$\frac{(\mathrm{O}-\mathrm{E})}{\text { S.E. }}$} \\
\hline & & & $\begin{array}{c}\text { Observed } \\
\text { (O) }\end{array}$ & $\begin{array}{l}\text { Expected } \\
\text { (E) }\end{array}$ & & & \\
\hline $\begin{array}{c}\text { Males } \\
1\end{array}$ & $\begin{array}{l}\mathbf{N} \\
\mathbf{B}\end{array}$ & $\begin{array}{r}3 \\
10\end{array}$ & $\begin{array}{l}3.63 \\
3.34\end{array}$ & $\begin{array}{l}4 \cdot 08 \\
3.56\end{array}$ & $\begin{array}{l}-0.45 \\
-0.22\end{array}$ & $\begin{array}{l}0 \cdot 36 \\
0 \cdot 20\end{array}$ & $\begin{array}{l}-1.26 \\
-1.12\end{array}$ \\
\hline 2 & $\underset{\mathbf{B}}{\mathbf{N}}$ & $\begin{array}{l}31 \\
33\end{array}$ & $\begin{array}{l}3 \cdot 73 \\
3 \cdot 57\end{array}$ & $\begin{array}{l}3.94 \\
3.81\end{array}$ & $\begin{array}{l}-0.21 \\
-0.24\end{array}$ & $\begin{array}{l}0.11 \\
0.11\end{array}$ & $\begin{array}{l}-1 \cdot 83 \\
-2 \cdot 16\end{array}$ \\
\hline 3 & $\begin{array}{l}\mathbf{N} \\
\mathbf{B}\end{array}$ & $\begin{array}{l}4 \\
7\end{array}$ & $\begin{array}{l}3.85 \\
3.01\end{array}$ & $\begin{array}{l}3.96 \\
3.51\end{array}$ & $\begin{array}{l}-0.11 \\
-0.50\end{array}$ & $\begin{array}{l}0.31 \\
0.24\end{array}$ & $\begin{array}{l}-0.35 \\
-2 \cdot 11 \ddagger\end{array}$ \\
\hline 4 & $\begin{array}{l}\mathbf{N} \\
\mathbf{B}\end{array}$ & $\begin{array}{l}18 \\
14\end{array}$ & $\begin{array}{l}3.41 \\
3.34\end{array}$ & $\begin{array}{l}3.65 \\
3 \cdot 72\end{array}$ & $\begin{array}{l}-0.24 \\
-0.38\end{array}$ & $\begin{array}{l}0 \cdot 15 \\
0 \cdot 17\end{array}$ & $\begin{array}{l}-1 \cdot 61 \\
-2 \cdot 27 \ddagger\end{array}$ \\
\hline 5 & $\begin{array}{l}\mathbf{N} \\
\mathbf{B}\end{array}$ & $\begin{array}{l}5 \\
1\end{array}$ & $\begin{array}{l}4 \cdot 38 \\
3 \cdot 70\end{array}$ & $\begin{array}{l}4.05 \\
3.67\end{array}$ & $\begin{array}{l}0.33 \\
0.03\end{array}$ & $\begin{array}{l}0.28 \\
0.62\end{array}$ & $\begin{array}{l}1.19 \\
0.05\end{array}$ \\
\hline 6 & $\stackrel{\mathbf{N}}{\mathbf{B}}$ & $\begin{array}{r}18 \\
7\end{array}$ & $\begin{array}{l}3.33 \\
3.97\end{array}$ & $\begin{array}{r}3.80 \\
3.94\end{array}$ & $\begin{array}{r}-0.47 \\
0.03\end{array}$ & $\begin{array}{l}0 \cdot 15 \\
0 \cdot 23\end{array}$ & $\begin{array}{c}-3 \cdot 17 \ddagger \\
0 \cdot 13\end{array}$ \\
\hline 7 & $\begin{array}{l}\mathbf{N} \\
\mathbf{B}\end{array}$ & $\begin{array}{l}4 \\
4\end{array}$ & $\begin{array}{l}3.70 \\
3.05\end{array}$ & $\begin{array}{l}3.52 \\
3.82\end{array}$ & $\begin{array}{r}0.18 \\
-0.77\end{array}$ & $\begin{array}{l}0.31 \\
0.31\end{array}$ & $\begin{array}{c}0.58 \\
-2 \cdot 48 \ddagger\end{array}$ \\
\hline 8 & $\begin{array}{l}\mathbf{N} \\
\mathbf{B}\end{array}$ & $\begin{array}{r}13 \\
6 \\
\end{array}$ & $\begin{array}{l}3.58 \\
3.62 \\
\end{array}$ & $\begin{array}{r}3 \cdot 70 \\
3 \cdot 84 \\
\end{array}$ & $\begin{array}{l}-0.12 \\
-0.22 \\
\end{array}$ & $\begin{array}{l}0.17 \\
0.25\end{array}$ & $\begin{array}{l}-0.69 \\
-0.87\end{array}$ \\
\hline $\begin{array}{c}\text { Females } \\
1\end{array}$ & $\underset{\mathbf{B}}{\mathbf{N}}$ & $\begin{array}{l}24 \\
22\end{array}$ & $\begin{array}{l}2 \cdot 81 \\
2 \cdot 62\end{array}$ & $\begin{array}{l}2 \cdot 73 \\
2 \cdot 74\end{array}$ & $\begin{array}{r}0.08 \\
-0.12\end{array}$ & $\begin{array}{l}0.09 \\
0.09\end{array}$ & $\begin{array}{r}0.93 \\
-1.34\end{array}$ \\
\hline 2 & $\begin{array}{l}\mathbf{N} \\
\mathbf{B}\end{array}$ & $\begin{array}{l}28 \\
18\end{array}$ & $\begin{array}{l}2 \cdot 80 \\
2 \cdot 77\end{array}$ & $\begin{array}{l}2 \cdot 90 \\
2 \cdot 85\end{array}$ & $\begin{array}{l}-0.10 \\
-0.08\end{array}$ & $\begin{array}{l}0.08 \\
0 \cdot 10\end{array}$ & $\begin{array}{l}-1.25 \\
-0.81\end{array}$ \\
\hline 3 & $\begin{array}{l}\mathbf{N} \\
\mathbf{B}\end{array}$ & $\begin{array}{l}25 \\
10\end{array}$ & $\begin{array}{l}2 \cdot 88 \\
2.55\end{array}$ & $\begin{array}{l}2 \cdot 87 \\
2 \cdot 76\end{array}$ & $\begin{array}{r}0.01 \\
-0.21\end{array}$ & $\begin{array}{l}0.08 \\
0.13\end{array}$ & $\begin{array}{r}0.12 \\
-1.59\end{array}$ \\
\hline 4 & $\underset{\mathbf{B}}{\mathbf{N}}$ & $\begin{array}{l}17 \\
13\end{array}$ & $\begin{array}{l}2.75 \\
2.64\end{array}$ & $\begin{array}{l}2 \cdot 89 \\
2 \cdot 71\end{array}$ & $\begin{array}{l}-0.14 \\
-0.07\end{array}$ & $\begin{array}{l}0.10 \\
0.12\end{array}$ & $\begin{array}{l}-1 \cdot 38 \\
-0.60\end{array}$ \\
\hline 5 & $\stackrel{\mathbf{N}}{\mathbf{B}}$ & $\begin{array}{l}73 \\
23\end{array}$ & $\begin{array}{l}2 \cdot 44 \\
2 \cdot 27\end{array}$ & $\begin{array}{l}2 \cdot 42 \\
2 \cdot 47\end{array}$ & $\begin{array}{r}0.02 \\
-0.20\end{array}$ & $\begin{array}{l}0.05 \\
0.09\end{array}$ & $\begin{array}{c}0.39 \\
-2.29 \ddagger\end{array}$ \\
\hline 6 & $\underset{\mathbf{B}}{\mathbf{N}}$ & $\begin{array}{r}106 \\
24\end{array}$ & $\begin{array}{l}2 \cdot 62 \\
2 \cdot 42\end{array}$ & $\begin{array}{l}2 \cdot 68 \\
2 \cdot 54\end{array}$ & $\begin{array}{l}-0.06 \\
-0 \cdot 12\end{array}$ & $\begin{array}{l}0.04 \\
0.09\end{array}$ & $\begin{array}{l}-1.41 \\
-1.40\end{array}$ \\
\hline 7 & $\underset{\mathbf{B}}{\mathbf{N}}$ & $\begin{array}{l}42 \\
14\end{array}$ & $\begin{array}{l}2 \cdot 37 \\
2 \cdot 40\end{array}$ & $\begin{array}{l}2 \cdot 51 \\
2 \cdot 61\end{array}$ & $\begin{array}{l}-0.14 \\
-0.21\end{array}$ & $\begin{array}{l}0.07 \\
0.11\end{array}$ & $\begin{array}{l}-2.12 \ddagger \\
-1.89\end{array}$ \\
\hline 8 & $\begin{array}{l}\mathbf{N} \\
\mathbf{B}\end{array}$ & $\begin{array}{l}60 \\
11 \\
\end{array}$ & $\begin{array}{l}2 \cdot 65 \\
2.59\end{array}$ & $\begin{array}{l}2 \cdot 72 \\
2 \cdot 78\end{array}$ & $\begin{array}{l}-0.07 \\
-0.19\end{array}$ & $\begin{array}{l}0.06 \\
0.13\end{array}$ & $\begin{array}{l}-1.26 \\
-1.51\end{array}$ \\
\hline
\end{tabular}

* See footnote (2) to Table 1.

$+\mathbf{N}=$ byssinosis grade $\mathbf{0} ; \mathbf{B}=$ byssinosis grades $\frac{1}{2}, \mathbf{I}$, and $\mathbf{I I}$.

† Significant at $P<0.05$. 
TABLE 10

NINETY-FIVE PER CENT CONFIDENCE LIMITS OF DEVIATIONS (OBSERVED - EXPECTED) OF F.E.V.1.0 AND F.V.C. FOR NON-BYSSINOTIC (GRADE O) AND BYSSINOTIC (GRADES $\frac{1}{2}$, I, AND II) PREPARERS IN EACH BASIC GROUP*

\begin{tabular}{|c|c|c|c|c|c|}
\hline \multirow{3}{*}{ 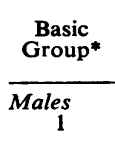 } & \multirow{3}{*}{$\begin{array}{c}\begin{array}{c}\text { Byssinosis } \\
\text { Grade } \dagger\end{array} \\
\underset{\mathbf{N}}{\mathbf{N}}\end{array}$} & \multicolumn{4}{|c|}{$95 \%$ Confidence Limits of Deviations in } \\
\hline & & \multicolumn{2}{|c|}{ F.E.V.1.0 } & \multicolumn{2}{|c|}{ F.V.C. } \\
\hline & & $\begin{array}{l}-0.99 \text { to } \\
-0.78\end{array}$ & $\begin{array}{r}0.27 \\
-0.08\end{array}$ & $\begin{array}{l}-1.16 \text { to } \\
-0.61\end{array}$ & $\begin{array}{l}0.26 \\
0 \cdot 17\end{array}$ \\
\hline 2 & $\begin{array}{l}\mathbf{N} \\
\mathbf{B}\end{array}$ & $\begin{array}{l}-0.38 \\
-0.36\end{array}$ & $\begin{array}{l}0.02 \\
0.04\end{array}$ & $\begin{array}{l}-0.43 \\
-0.46\end{array}$ & $\begin{array}{r}0.01 \\
-0.02\end{array}$ \\
\hline 3 & $\begin{array}{l}\mathbf{N} \\
\mathbf{B}\end{array}$ & $\begin{array}{l}-0.65 \\
-0.83\end{array}$ & $\begin{array}{r}0.45 \\
-0.01\end{array}$ & $\begin{array}{l}-0.72 \\
-0.97\end{array}$ & $\begin{array}{r}0.50 \\
-0.03\end{array}$ \\
\hline 4 & $\begin{array}{l}\mathbf{N} \\
\mathbf{B}\end{array}$ & $\begin{array}{l}-0.39 \\
-0.51\end{array}$ & $\begin{array}{l}0.13 \\
0.09\end{array}$ & $\begin{array}{l}-0.54 \\
-0.71\end{array}$ & $\begin{array}{r}0.06 \\
-0.05\end{array}$ \\
\hline 5 & $\begin{array}{l}\mathbf{N} \\
\mathbf{B}\end{array}$ & $\begin{array}{l}-0.28 \\
-0.92\end{array}$ & $\begin{array}{l}0.70 \\
1 \cdot 24\end{array}$ & $\begin{array}{l}-0.22 \\
-1 \cdot 19\end{array}$ & $\begin{array}{l}0.88 \\
1.25\end{array}$ \\
\hline 6 & $\begin{array}{l}\mathbf{N} \\
\mathbf{B}\end{array}$ & $\begin{array}{l}-0.65 \\
-0.74\end{array}$ & $\begin{array}{r}-0.13 \\
0.08\end{array}$ & $\begin{array}{l}-0.77 \\
-0.42\end{array}$ & $\begin{array}{r}-0.17 \\
0.48\end{array}$ \\
\hline 7 & $\begin{array}{l}\mathbf{N} \\
\mathbf{B}\end{array}$ & $\begin{array}{l}-0.32 \\
-1.57\end{array}$ & $\begin{array}{r}0.78 \\
-0.47\end{array}$ & $\begin{array}{l}-0.43 \\
-1.38\end{array}$ & $\begin{array}{r}0.79 \\
-0.16\end{array}$ \\
\hline 8 & $\begin{array}{l}\mathbf{N} \\
\mathbf{B}\end{array}$ & $\begin{array}{l}-0.48 \\
-0.71 \\
\end{array}$ & $\begin{array}{l}0.12 \\
0.15 \\
\end{array}$ & $\begin{array}{l}-0.45 \\
-0.71 \\
\end{array}$ & $\begin{array}{l}0.21 \\
0.27 \\
\end{array}$ \\
\hline $\begin{array}{c}\text { Females } \\
1\end{array}$ & $\begin{array}{l}\mathbf{N} \\
\mathbf{B}\end{array}$ & $\begin{array}{l}-0.07 \text { to } \\
-0.32\end{array}$ & $\begin{array}{l}0.25 \\
0.00\end{array}$ & $\begin{array}{l}-0.10 \text { to } \\
-0.30\end{array}$ & $\begin{array}{l}0.26 \\
0.06\end{array}$ \\
\hline 2 & $\begin{array}{l}\mathbf{N} \\
\mathbf{B}\end{array}$ & $\begin{array}{l}-0.18 \\
-0.24\end{array}$ & $\begin{array}{l}0 \cdot 10 \\
0 \cdot 12\end{array}$ & $\begin{array}{l}-0.26 \\
-0.28\end{array}$ & $\begin{array}{l}0.06 \\
0 \cdot 12\end{array}$ \\
\hline 3 & $\begin{array}{l}\mathbf{N} \\
\mathbf{B}\end{array}$ & $\begin{array}{l}-0.17 \\
-0.45\end{array}$ & $\begin{array}{l}0.15 \\
0.03\end{array}$ & $\begin{array}{l}-0.15 \\
-0.47\end{array}$ & $\begin{array}{l}0.17 \\
0.05\end{array}$ \\
\hline 4 & $\begin{array}{l}\mathbf{N} \\
\mathbf{B}\end{array}$ & $\begin{array}{l}-0.34 \\
-0.35\end{array}$ & $\begin{array}{l}0.02 \\
0.05\end{array}$ & $\begin{array}{l}-0.34 \\
-0.31\end{array}$ & $\begin{array}{l}0.06 \\
0.17\end{array}$ \\
\hline 5 & $\begin{array}{l}\mathbf{N} \\
\mathbf{B}\end{array}$ & $\begin{array}{l}-0.14 \\
-0.43\end{array}$ & $\begin{array}{r}0.06 \\
-0.11\end{array}$ & $\begin{array}{l}-0.08 \\
-0.38\end{array}$ & $\begin{array}{r}0.12 \\
-0.02\end{array}$ \\
\hline 6 & $\begin{array}{l}\mathbf{N} \\
\mathbf{B}\end{array}$ & $\begin{array}{l}-0.14 \\
-0.33\end{array}$ & $\begin{array}{r}0.02 \\
-0.01\end{array}$ & $\begin{array}{l}-0 \cdot 14 \\
-0.30\end{array}$ & $\begin{array}{l}0.02 \\
0.06\end{array}$ \\
\hline 7 & $\begin{array}{l}\mathbf{N} \\
\mathbf{B}\end{array}$ & $\begin{array}{l}-0.29 \\
-0.47\end{array}$ & $\begin{array}{l}-0.05 \\
-0.07\end{array}$ & $\begin{array}{l}-0.28 \\
-0.43\end{array}$ & $\begin{array}{l}0.00 \\
0.01\end{array}$ \\
\hline 8 & $\begin{array}{l}\mathbf{N} \\
\mathbf{B}\end{array}$ & $\begin{array}{l}-0.19 \\
-0.41\end{array}$ & $\begin{array}{l}0.01 \\
0.03\end{array}$ & $\begin{array}{l}-0.19 \\
-0.45\end{array}$ & $\begin{array}{l}0.05 \\
0.07\end{array}$ \\
\hline
\end{tabular}

*See footnote (2) to Table 1.

$\dagger \mathbf{N}=$ byssinosis grade $\mathbf{0}$; $\mathbf{B}=$ byssinosis grades $\frac{1}{2}$, I, and II.

tions of average F.V.C. are given in Table 10. Again the imprecise nature of these estimates calls for care in making generalizations from them.

There were five basic groups of men and five of women in which the deviations were negative both for the byssinotic and the non-byssinotic sub-groups. In four out of these five male groups and in three out of these five female groups, the negative deviations were of greater magnitude in the byssinotic than in the non-byssinotic sub-group within the same basic group. As with F.E.V.1.0, this observation is compatible with the hypothesis that byssinotic preparers suffer greater impairment of lung function than do non-byssinotic preparers. On the null hypothesis, the probability of observing by chance, out of 10 pairs, as many as seven pairs of deviations, in which one particular member is greater than the other, is not, however, very low, $0 \cdot 171$.

In the remaining basic groups of both men and women, where the signs of the deviations in the byssinotic and non-byssinotic sub-groups were not negative, the former, with one exception, had the less favourable F.V.C. In the exceptional basic group, a male group, the byssinotic sub-group had a non-significant positive deviation whereas the nonbyssinotic sub-group had a significant negative deviation-an unexpected inconsistency unless the argument is invoked that by chance $5 \%$ of all deviations are likely to be designated significant even on the null hypothesis. In one basic group of men and in one of women, the byssinotic sub-group had a significant negative deviation whereas the nonbyssinotic sub-group had a positive, but not significant, deviation.

There is again considerable overlap of the $95 \%$ confidence limits of the deviations of the byssinotic and non-byssinotic sub-groups within most basic groups.

Byssinosis Grade and Lung Function Estimates.It is of interest to look for evidence of an association between the severity of symptoms, as indicated by byssinosis grade (Elwood et al., 1965) and lung function estimates. Even though the numbers in some byssinotic grades are very small, this has been attempted. Tables 11 and 12 show deviations, calculated as before, for average F.E.V.1.0 respectively for sub-groups of preparers determined by their byssinotic grade $0, \frac{1}{2}, \mathrm{I}$, and II, for each of the eight basic groups of each sex, in which workers in these grades were found. As the severity of symptoms increases, by definition, from grade 0 to grade II, it is reasonable to expect that the deviations in average F.E.V $\cdot_{\cdot 1 \cdot 0}$ and average F.V.C. would follow a trend compatible with increasing impairment of lung function. When within a basic group of one sex all the deviations are negative, such a trend would be shown by an increasing magnitude of negative deviations from grade 0 to grade II. When some of the deviations are positive and some negative, such a trend would be shown by the positive deviations decreasing in magnitude followed by the negative deviations increasing in magnitude from grade 0 to grade II. In the next two sections the examination is largely a search for such trends within each basic group of each sex.

Byssinosis Grade and F.E.V.1.0.-Table 11 shows that of the 29 deviations tabulated for male preparers and of the 32 tabulated for female preparers, as many as 22 and 30 respectively were negative. Six 
TABLE 11

DEVIATIONS (OBSERVED - EXPECTED AVERAGE F.E.V.1.0) IN LITRES IN EACH BYSSINOSIS GRADE OF PREPARERS IN EACH BASIC GROUP:

\begin{tabular}{|c|c|c|c|c|c|c|c|}
\hline \multirow{2}{*}{$\underset{\text { Group }}{\text { Basic }}$} & \multicolumn{7}{|c|}{ Byssinosis Grade } \\
\hline & 0 & & $\frac{1}{2}$ & I & & II & \\
\hline $\begin{array}{r}\text { Males } \\
1 \\
2 \\
3 \\
4 \\
5 \\
6 \\
7 \\
8\end{array}$ & $\begin{array}{c}-0.36 \\
-0.18 \\
-0.10 \\
-0.13 \\
0.21 \\
-0.39 \dagger \\
0.23 \\
-0.18\end{array}$ & $\begin{array}{r}(3) \\
(31) \\
(4) \\
(18) \\
(5) \\
(18) \\
(4) \\
(13)\end{array}$ & $\begin{array}{rr}-0.21 & (6) \\
-0.10 & (18) \\
-0.65 & (2) \\
0.04 & (4) \\
0.16 & (1) \\
0.18 & (2) \\
-0.48 & \left(\frac{1}{(3)}\right.\end{array}$ & $\begin{array}{r}-0.57 \\
0.21 \\
-0.38 \\
-0.37 \\
-0.39 \\
-1.00 \dagger \\
0.01\end{array}$ & $\begin{array}{l}(2) \\
(7) \\
(3) \\
(4) \\
(-) \\
(4) \\
(2) \\
(1)\end{array}$ & $\begin{array}{l}-0.98 \dagger \\
-0.63 \dagger \\
-0.24 \\
-0.27 \\
-1 . \overline{13}+ \\
-1.04 \dagger \\
-0.13\end{array}$ & $\begin{array}{l}(2) \\
(8) \\
(2) \\
(6) \\
(1) \\
(1) \\
(2) \\
(2)\end{array}$ \\
\hline $\begin{array}{c}\text { Females } \\
1 \\
2 \\
3 \\
4 \\
5 \\
6 \\
7 \\
8\end{array}$ & $\begin{array}{l}0.09 \\
-0.04 \\
-0.01 \\
-0.16 \\
-0.04 \\
-0.06 \\
-0.17 \dagger \\
-0.09\end{array}$ & $\begin{array}{l}(24) \\
(28) \\
(25) \\
(17) \\
(73) \\
(106) \\
(42) \\
(60)\end{array}$ & $\begin{array}{rr}-0.15 & (8) \\
0.03 & (9) \\
-0.13 & (4) \\
-0.11 & \text { (5) } \\
-0.35 & (9) \\
-0.17 & \text { (16) } \\
-0.29 \dagger & \text { (7) } \\
-0.03 & (4)\end{array}$ & $\begin{array}{l}-0.20 \\
-0.21 \\
-0.23 \\
-0.20 \\
-0.30 \dagger \\
-0.14 \\
-0.16 \\
-0.17\end{array}$ & $\begin{array}{l}(8) \\
(6) \\
(5) \\
(5) \\
(8) \\
(6) \\
(4) \\
(4)\end{array}$ & $\begin{array}{l}-0.10 \\
-0.03 \\
-0.38 \\
-0.13 \\
-0.10 \\
-0.24 \\
-0.34 \\
-0.41\end{array}$ & $\begin{array}{l}(6) \\
(3) \\
(1) \\
(3) \\
(6) \\
(2) \\
(3) \\
(3)\end{array}$ \\
\hline
\end{tabular}

*See footnote (2) to Table 1.

Number of workers in group and byssinosis grade shown in parentheses.

$\dagger$ Significant at $\mathbf{P}<0.05$.

TABLE 12

DEVIATIONS (OBSERVED - EXPECTED AVERAGE F.V.C.) IN LITRES IN EACH BYSSINOSIS GRADE OF PREPARERS IN EACH BASIC GROUP*

\begin{tabular}{|c|c|c|c|c|c|}
\hline \multirow{2}{*}{$\underset{\text { Group* }}{\text { Basic }}$} & \multicolumn{5}{|c|}{ Byssinosis Grade } \\
\hline & 0 & & $\frac{1}{2}$ & I & II \\
\hline $\begin{array}{r}\text { Males } \\
1 \\
2 \\
3 \\
4 \\
5 \\
6 \\
7 \\
7 \\
8\end{array}$ & $\begin{array}{r}-0.45 \\
-0.21 \\
-0.11 \\
-0.24 \\
0.33 \\
-0.47 \\
0.18 \\
-0.12\end{array}$ & $\begin{array}{l}(3) \\
(31) \\
(4) \\
(18) \\
(5) \\
(18) \\
(4) \\
(13)\end{array}$ & $\begin{array}{cc}-0.20 & (6) \\
-0.12 & (18) \\
-0.74 & (2) \\
-0.01 & (4) \\
0.03 & (1) \\
0.98 \dagger & (2) \\
-0.40 & \left(\frac{1}{(3)}\right) \\
-0.40 & \end{array}$ & $\begin{array}{rr}0.36 & (2) \\
0.03 & (7) \\
-0.32 & (3) \\
-0.60 & (4) \\
-0.26 & \left(\frac{(4)}{(4)}\right. \\
-0.63 & (2) \\
-0.27 & (1)\end{array}$ & $\begin{array}{c}-0.85 \\
-0.76 \dagger \quad(2) \\
-0.49 \quad(2) \\
-0.48 \quad(6) \\
-0.67 \quad\left(\frac{1}{(1)}\right. \\
-0.91 \dagger \quad(2) \\
0.05 \quad(2)\end{array}$ \\
\hline $\begin{array}{c}\text { male } \\
1 \\
2 \\
3 \\
4 \\
5 \\
6 \\
7 \\
8\end{array}$ & $\begin{array}{r}0.08 \\
-0.10 \\
0.01 \\
-0.14 \\
0.02 \\
-0.06 \\
-0.14 \\
-0.07\end{array}$ & $\begin{array}{r}(24) \\
(28) \\
(25) \\
(17) \\
(73) \\
(106) \\
(42) \\
(60)\end{array}$ & $\begin{array}{cc}0.01 & (8) \\
0.04 & (9) \\
-0.11 & (4) \\
-0.12 & (5) \\
-0.30 \dagger & (9) \\
-0.12 & (16) \\
-0.23 & (7) \\
-0.01 & (4)\end{array}$ & $\begin{array}{ll}-0.20 & (8) \\
-0.35 \dagger & (6) \\
-0.20 & (5) \\
-0.10 & (5) \\
0.15 & (8) \\
-0.08 & (6) \\
-0.14 & (4) \\
-0.20 & (4)\end{array}$ & 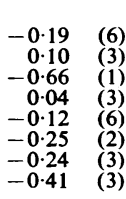 \\
\hline
\end{tabular}

* See footnote (2) to Table 1.

Number of workers in group and byssinosis grade shown in parentheses.

†Significant at $P<0.05$.

negative deviations in the male groups and four in the female were significant. In male groups, four of the significant negative deviations occurred in byssinosis grade II, one in grade I, and one in grade 0 . In female groups, one of the significant deviations occurred in byssinosis grade $I$, two in grade $\frac{1}{2}$, and one in grade 0 . Within the basic groups, consistent trends of the type described in the previous section occurred only once, in a female group in which all deviations were negative. The maximum negative deviation, within a basic group, occurred in byssinosis grades I or II in five of the seven basic groups of men and in seven of the eight basic groups of women. On the null hypothesis, the probability of observing, out of 15 , as many as 12 maximum negative deviations in byssinosis grades $\mathbf{I}$ or II, rather than in 0 or $\frac{1}{2}$, is low, 0.018 .

Byssinosis Grade and F.V.C.-Table 12 shows that of the 29 deviations tabulated for male preparers and of the 32 tabulated for female preparers, as many as 22 and 24 respectively were negative. Three negative deviations in the male groups and three in the female groups were significant. One positive deviation in the male groups was also significant (basic group 6, byssinosis grade $\frac{1}{2}$ ), and this resulted in the exceptional result referred to earlier when the F.V.C. was considered for byssinotic preparers ignoring grade. In male groups, two of the significant negative deviations occurred in byssinosis grade II and one in grade 0 . In female groups, one of the significant negative deviations occurred in byssinosis grade $\mathrm{I}$, one in grade $\frac{1}{2}$, and one in grade 0 . Within the basic groups, consistent trends of the type described in the penultimate section occurred only once, in a female group in which the deviation in grade 0 was positive in contrast to negative deviations in the remaining grades. The maximum negative deviation, within a basic group, occurred in byssinosis grades I or II in five of the seven basic groups of men and in six of the eight basic groups of women. On the null hypothesis, the probability of observing, out of 15, as many as 11 maximum negative deviations in byssinosis grades I or II, rather than in grades 0 or $\frac{1}{2}$, is 0.059 .

\section{Discussion}

The following conclusions are, by the nature of the analysis on which they are based, unlikely to be explained by the effects of any of the secondary factors which have been considered, and these conclusions should be read with the qualification that such secondary factors are held constant.

The preponderance of negative deviations in Table 8 leaves little room for doubt that both byssinotic and non-byssinotic preparers have a lower average F.E.V.1.0 than non-byssinotic nonpreparers.

The preponderance of negative deviations in the byssinotic sub-groups in Table 9 also leaves little room for doubt that byssinotic preparers have a lower average F.V.C. than non-byssinotic nonpreparers. The evidence in favour of a similar 
conclusion with regard to non-byssinotic preparers and non-byssinotic non-preparers is slightly less convincing.

A comparison of byssinotic with non-byssinotic sub-groups of preparers, within basic groups in Tables 8 and 9 , suggests that the average F.E.V.1.0 of the former is lower than that of the latter, but the evidence for a similar conclusion with regard to the average F.V.C. is less convincing.

No definite association between either F.E.V.1.0 F.V.C. and byssinosis grade can be deduced from the results shown in Tables 11 and 12, but with the numbers involved this is not surprising. The results are certainly compatible with the hypothesis that the average F.E.V.1.0 or II is lower than those in grades 0 or $\frac{1}{2}$. We may be unduly cautious in not drawing a similar conclusion in respect of F.V.C.

The best assessment of the magnitude of the deviations shown in Tables 8 and 9 appears in the $95 \%$ confidence limits of Table 10 . The sampling errors are too large to quote values out of their context. For any particular sub-group of preparers (i.e., defined by byssinotic state, sex, current smoking habits, type of fibre handled, and location of mill) the table gives limits within which one can expect, with a high degree of confidence, to find the true average difference in F.E.V.1.0 or F.V.C. between each defined sub-group and a comparable group of non-byssinotic non-preparers of the same average age and stem height.

The results presented here indicate that impairment of ventilatory capacity occurs in flax preparers. Tables 8 and 9 indicate that this impairment, in at least some of the basic groups, was great enough to be clinically important. It is not, however, possible to reach a conclusion from these data as to whether the impairment was temporary or permanent, or both.

Acute temporary impairment of lung function is known to occur on Mondays, and on other days of the week, in cotton cardroom workers with grades I and II byssinosis (McKerrow et al., 1958), and in byssinotic flax workers on Mondays and Thursdays (Mair, Smith, Wilson, and Lockhart, 1960). A later experiment (Carey and Merrett, 1965) showed that (1) a significant decline in F.E.V.$_{1 \cdot 0}$ and F.V.C. can occur in grade II byssinotic flax workers on Monday, Tuesday, and Wednesday, and (2) non-byssinotic control subjects also show some decline in F.E.V.1.0 and F.V.C. on most days of the week.

These findings in cotton and in flax workers are of considerable relevance to the present data. As workers were examined at all times during the working day in the present study, any change in lung function during the day will, in a group of byssinotic preparers, be confounded with any change which does not show such a diurnal rhythm. Therefore, although there may be two effects on ventilatory capacity caused by exposure to flax dust-a relatively 'permanent' change together with a relatively 'acute' and reversible daily change - these two effects are confounded in the present data. This is of relevance to all the comparisons between preparers and non-preparers presented in this report. Furthermore, although we have no reason to believe that byssinotic workers were more likely to attend for interview and lung function test towards the end of the day, yet the fact that the diurnal fall in lung function found by Carey and Merrett (1965) was greater on most working days of the week in the byssinotic than in the control group implies that bias from the 'acute' effect will affect any comparison between byssinotic and non-byssinotic preparers which purports to estimate the 'permanent' disability of byssinosis.

The investigation was supported in part by a grant from the Northern Ireland Ministry of Labour and National Insurance. We wish to thank the Northern Ireland Flax Spinners' Association Ltd., the textile branch of the Amalgamated and General Workers Trade Union, and the Managers, staff, and employees of the mills surveyed for the great help and co-operation which we received from them.

We wish to thank Professor E. A. Cheeseman for statistical advice and Miss J. Broderick, Mrs. D. Hutton, Miss B. Jackson, Mrs. E. E. Kingston, Mrs. J. J. McCabe, Mrs. L. A. McCreight, Miss T. Pitt, and Miss S. J. Smith for help in preparing this paper.

\section{REFERENCES}

Carey, G. C. R., and Merrett, J. D. (1965). Brit. J. industr. Med.,

College of General Practitioners (1961). Brit. med. J., 2, 973.

Elwood, P. C., Pemberton, J., Merrett, J. D., Carey, G. C. R., and McAulay, I. R. (1965). Brit. J. industr. Med., 22, 27.

Gaensler, E. A. (1951). Amer. Rev. Tuberc., 64, 256.

Higgins, I. T. T. (1957). Brit. med. J., 2, 1198.

Hurtado, A., and Fray, W. W. (1933). J. clin. Invest., 12, 823 Hurtado, A., and Fray, W. W. (1933). J. clin. Invest., 12, 823. .

$-, \frac{1,149 .}{15,}, \frac{75}{\text {, }}$, and Schilling, R. S. F. (1958). Brit. J. industr. Med.,

Mair, A., Smith, D. H., Wilson, W. A., and Lockhart, W. (1960). Ibid., 17, 272.

Needham, C. D., Rogan, M. C., and McDonald, I. (1954). Thorax, 9, 313.

Ogilvie, A. G., and Newell, D. J. (1957). Chronic Bronchitis in Newcastle upon Tyne, Livingstone, London.

Pemberton, J., and Macleod, K. I. E. (1956). Publ. Hlth Rep. (Wash.), 71, 1214.

Roach, S. A., and Schilling, R. S. F. (1960). Brit. J. industr. Med.,

Schilling, R. S. F., Hughes, J. P. W., Dingwall-Fordyce, I., and Gilson, J. C.'(1955). Ibid., 12, 217. 